\title{
Konsumsi tuak mempengaruhi terjadinya erosi gigi di Kecamatan Maiwa Kabupaten Enrekang (Palm wine consumption affects the incidence of dental erosion in Maiwa, Enrekang)
}

\author{
${ }^{1}$ Rizky Noviyanti, ${ }^{2}$ Indrya Kirana Mattulada \\ ${ }^{1}$ Mahasiswa tahap profesi \\ ${ }^{2}$ Bagian Konservasi Gigi \\ Fakultas Kedokteran, Gigi Universitas Hasanuddin \\ Makassar, Indonesia
}

\begin{abstract}
Palm wine from the palm is a typical drink of Maiwa, Enrekang. Bitter palm wine taken from fermented fruit of sugar plant intercepts (Arenga pinnata) which is called sap. Excessive drinking palm wine can cause pathological effects in the oral cavity, because the Palm wine have acidic $p H$ that can affect the occurrence of dental erosion. The purpose of this study was to determine the effect of palm wine consumption on the occurrence of dental erosion. This observational analytic with cross sectional approach showed that from 100 samples, 75 people had suffered dental erosion due to bitter palm wine consumption and 25 people did not suffer dental erosion because they consumed sweet palm wine only. So, it was concluded that palm wine consumption affects the dental erosion in Maiwa, Enrekang.
\end{abstract}

Keywords: dental erosion, palm wine, Arenga pinnata

\begin{abstract}
ABSTRAK
Minuman tuak dari aren adalah minuman khas tradisional masyarakat Kecamatan Maiwa Kabupaten Enrekang. Minuman tuak pahit diambil dari hasil fermentasi bahan minuman/buah dari sadapan tanaman aren (Arenga pinnata) yang disebut nira. Mengkonsumsi minuman tuak secara berlebihan dapat menimbulkan efek patologis dalam rongga mulut, karena minuman tuak memiliki $\mathrm{pH}$ yang asam sehingga dapat menyebabkan erosi gigi. Penelitian ini dimaksudkan untuk mengetahui pengaruh konsumsi minuman tuak terhadap terjadinya erosi gigi. Penelitian observasi analitik dengan pendekatan cross sectional study menunjukkan bahwa dari 100 orang yang menjadi sampel, diperoleh 75 orang yang memiliki erosi gigi karena mengkonsumsi minuman tuak pahit, dan 25 orang tidak memiliki erosi gigi karena hanya mengkonsumsi minuman tuak manis. Disimpulkan bahwa konsumsi tuak mempengaruhi terjadinya erosi gigi di kecamatan Maiwa.
\end{abstract}

Kata kunci: erosi gigi, minuman tuak pahit, Arenga pinnata

Koresponden: Indrya Kirana M, Bagian Konservasi Gigi, Fakultas Kedokteran Gigi Universitas Hasanuddin, Jl. Kandea No.5 Makassar, Indonesia.E-mail: Indryamattulada@yahoo.com

\section{PENDAHULUAN}

Erosi gigi adalah kerusakan jaringan keras gigi yang terjadi karena faktor kimia, misalnya makanan atau minuman yang mengandung asam atau zat kimia yang dapat menyebabkan pengikisan email gigi. ${ }^{1,2}$

Minuman tuak dari aren adalah minuman khas tradisional yang diambil dari hasil fermentasi bahan minuman/buah yang mengandung gula dari sadapan tanaman aren (Arenga pinnata) yang disebut nira. ${ }^{3}$ Terdapat 2 macam rasa minuman tuak dari nira, yaitu tuak manis yang tidak mengalami fermentasi serta tuak pahit yang mengalami fermentasi. Tuak manis adalah minuman dari nira pohon aren yang rasanya manis dan diminum dari nira segar atau nira yang belum mengalami fermentasi. Sedangkan tuak pahit adalah minuman dari nira pohon aren yang rasanya pahit karena telah difermentasi. ${ }^{4}$

Makanan dan minuman yang mengandung asam mengakibatkan erosi gigi. Demineralisasi pada email terjadi apabila email berada pada kondisi asam atau $\mathrm{pH}$-nya di bawah 5,5, karena $\mathrm{pH}$ yang rendah dapat meningkatkan konsentrasi ion hidrogen yang akan merusak hidroksiapatit pada email gigi. ${ }^{5}$ Minuman tuak manis terdiri dari air $(88,8 \%)$, karbohidrat dalam bentuk sukrosa $(11,8 \%)$, protein $(0,23 \%)$, mineral $(0,03 \%)$, dan lemak $(0,02 \%)$. Minuman tuak pahit memiliki $\mathrm{pH}$ asam dan mengandung alkohol $4-5 \%{ }^{3}$

Kecamatan Maiwa merupakan salah satu daerah dataran tinggi yang terletak di Kabupaten Enrekang, sehingga banyak dijumpai pohon aren. Kecamatan Maiwajuga merupakan daerah yang beriklim dingin, sehingga masyarakat mengkonsumsi minuman tuak tersebut agar dapat menghangatkan badan setelah pulang kerja.

Penelitian ini dilakukan untuk mengetahui pengaruh konsumsi minuman tuak terhadap erosi gigi di Kecamatan Maiwa Kabupaten Enrekang.

\section{BAHAN DAN METODE}

Penelitian observasi analitik dengan rancangan cross sectional ini dilakukan dengan membagikan kuesioner kepada responden yang sesuai dengan kriteria seleksi, dilakukan pemeriksaan gigi anterior atas dan bawah, kemudian diskor menurut kriteria 
penilaian indeks erosi gigi dari Eccles and Jenkins (1996), yaitu 0: tidak ada erosi gigi; 1: lesi superfisial hanya pada permukaan email, terlihat email tipis dan mengkilap; 2: lesi terlokalisasi kurang dari 1/3 permukaan dentin (dentin mulai terbuka), terdapat lesi yang berbentuk cawan dan lekukan yang dalam pada email dan dentin; 3: lesi general, lebih dari 1/3 permukaan dentin, kehilangan banyak dentin. ${ }^{6,7}$

Data yang terkumpul diolah dengan program SPSS 16. Pengaruh antara usia, jenis kelamin, jenis dan frekuensi konsumsi minuman tuak terhadap erosi gigi dianalisis dengan uji statistik chi-square.

\section{HASIL}

Pada penelitian ini dilakukan pengukuran $\mathrm{pH}$ minuman tuak pada masing-masing Desa/Kelurahan. Tuakmanis yang diproduksi di Kelurahan Bangkala, Desa Mangkawani dan Puncak Harapan memiliki pH 7 (normal). Sedangkan minuman tuak pahit yang diproduksi di Kelurahan Bangkala memiliki pH 3,34, Desa Mangkawani memilikipH3,7 dan Desa Puncak Harapan memilik pH 4.

Pada tabel 1 menunjuk hasil uji chi square ada pengaruh yang signifikan antara penggolongan usia, jenis kelamin, dan pekerjaan terhadap kejadian erosi pada peminum tuak $(\mathrm{p}<0,05)$.

Uji chi square menunjukkan ada pengaruh yang signifikan antara tempat tinggal terhadap kejadian erosi pada peminum tuak; $p=0,00$ (tabel 2).

Uji chi square (tabel 3) menunjuk ada pengaruh yang signifikan antara jenis minuman tuak yang dikonsumsi terhadap kejadian erosi pada peminum tuak yang dilihat dari nilai $\mathrm{p}=0,00(<0,05)$.

Uji chi square (tabel 4) menunjukkan adanya pengaruh yang signifikan antara frekuensi konsumsi minuman tuak setiap hari, lama konsumsi minuman tuak, serta banyaknya tuak yang dikonsumsi setiap kali minum terhadap kejadian erosi pada peminum

Tabel 1 Penggolongan jenis kelamin, usia, dan jenis pekerjaan terhadap kejadian erosi gigi pada peminum tuak ( $\mathrm{p}$ $<0,05=*$ signifikan)

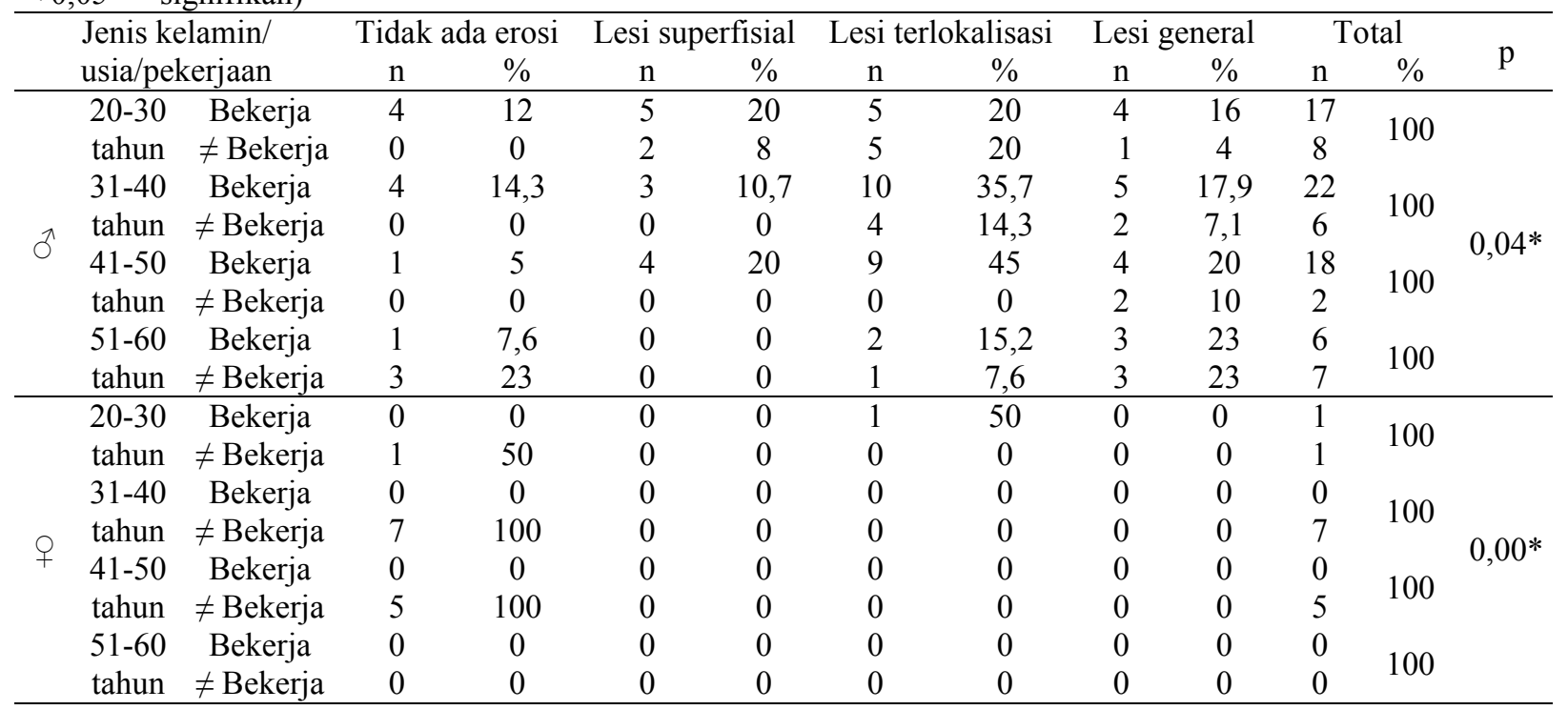

Tabel 2 Tempat tinggal dan kejadian erosi gigi pada peminum tuak $(\mathrm{p}<0,05=*$ signifikan $)$

\begin{tabular}{cccccccccccc}
\hline Desa/ & \multicolumn{2}{c}{ Tidak ada erosi } & \multicolumn{2}{c}{ Lesi superfisial } & \multicolumn{2}{c}{ Lesi terlokalisasi } & \multicolumn{2}{c}{ Lesi general } & \multicolumn{2}{c}{ Total } & \multirow{2}{*}{ P } \\
Kelurahan & $\mathrm{n}$ & $\%$ & $\mathrm{n}$ & $\%$ & $\mathrm{n}$ & $\%$ & $\mathrm{n}$ & $\%$ & $\mathrm{n}$ & $\%$ & \\
\hline Bangkala & 1 & 2,3 & 12 & 27,3 & 19 & 43,2 & 12 & 27,3 & 44 & 100 & \\
Mangkawani & 0 & 0 & 2 & 8,7 & 13 & 56,5 & 8 & 34,8 & 23 & 100 & \multirow{2}{*}{$0,00 *$} \\
Puncak Harapan & 24 & 72,7 & 0 & 0 & 5 & 15,2 & 4 & 12,1 & 33 & 100 \\
\hline Total & 25 & 25 & 14 & 14 & 37 & 37 & 24 & 24 & 100 & 100 & \\
\hline
\end{tabular}

Tabel 3 Penggolongan jenis minuman tuak terhadap erosi gigi pada peminum tuak $(\mathrm{P}<0,05=*$ signifikan $)$

\begin{tabular}{cccccccccccc}
\hline \multirow{2}{*}{ Jenis tuak } & Tidak ada erosi & \multicolumn{2}{c}{ Lesi superfisial } & \multicolumn{2}{c}{ Lesi terlokalisasi } & \multicolumn{2}{c}{ Lesi general } & \multicolumn{2}{c}{ Total } & $\mathrm{p}$ \\
& $\mathrm{n}$ & $\%$ & $\mathrm{n}$ & $\%$ & $\mathrm{n}$ & $\%$ & $\mathrm{n}$ & $\%$ & $\mathrm{n}$ & $\%$ & \\
\hline Tuak manis & 23 & 95,8 & 0 & 0,0 & 1 & 4,2 & 0 & 0,00 & 24 & 100 & \\
$\begin{array}{c}\text { Tuak pahit } \\
\text { Tuak manis \& } \\
\text { tuak pahit }\end{array}$ & 1 & 1,9 & 8 & 15,1 & 23 & 43,4 & 21 & 39,6 & 53 & 100 & \\
\hline Total & 25 & 4,3 & 6 & 26,1 & 13 & 56,5 & 3 & 13,0 & 23 & 100 & $0,00 *$ \\
\hline
\end{tabular}


Tabel 4 Pengaruh frekuensi, lamanya dan banyak konsumsi tuak terhadap erosi gigi $(\mathrm{p}<0,05=*$ signifikan $)$

\begin{tabular}{|c|c|c|c|c|c|c|c|c|c|c|c|c|c|}
\hline \multirow{2}{*}{\multicolumn{3}{|c|}{$\begin{array}{c}\text { frekuensi konsumsi } \\
\text { minuman tuak }\end{array}$}} & \multicolumn{2}{|c|}{ Tidak ada erosi } & \multicolumn{2}{|c|}{ Lesi superfisial } & \multicolumn{2}{|c|}{ Lesi terlokalisasi } & \multicolumn{2}{|c|}{ Lesi general } & \multicolumn{2}{|c|}{ Total } & \multirow{2}{*}{$\mathrm{P}$} \\
\hline & & & $\mathrm{n}$ & $\%$ & $\mathrm{n}$ & $\%$ & $\mathrm{n}$ & $\%$ & $\mathrm{n}$ & $\%$ & $\mathrm{n}$ & $\%$ & \\
\hline \multirow{6}{*}{$\begin{array}{l}\text { setiap } \\
\text { hari }\end{array}$} & $0-5$ & 1-2 gelas & 1 & 7,1 & 1 & 7,1 & 0 & 0 & 0 & 0 & 2 & \multirow{2}{*}{100} & \multirow{6}{*}{$0,03^{*}$} \\
\hline & tahun & $>3$ gelas & 1 & 7,1 & 6 & 42,9 & 4 & 28,6 & 1 & 7,1 & 12 & & \\
\hline & $6-10$ & 1-2 gelas & 0 & 0 & 0 & 0 & 0 & 0 & 0 & 0 & 0 & \multirow{2}{*}{100} & \\
\hline & tahun & $>3$ gelas & 1 & 6,66 & 1 & 6,66 & 3 & 19,9 & 10 & 66,6 & 15 & & \\
\hline & $>10$ & 1-2 gelas & 0 & 0 & 0 & 0 & 0 & 0 & 0 & 0 & 0 & \multirow{2}{*}{100} & \\
\hline & tahun & $>3$ gelas & 0 & 0 & 0 & 0 & 6 & 33,4 & 12 & 66,9 & 18 & & \\
\hline \multirow{6}{*}{$\begin{array}{l}\text { setiap } \\
\text { minggu }\end{array}$} & $0-5$ & $1-2$ gelas & 0 & 0 & 1 & 6,3 & 0 & 0 & 0 & 0 & 1 & \multirow[b]{2}{*}{100} & \multirow{6}{*}{0,012} \\
\hline & tahun & $>3$ gelas & 2 & 12,5 & 5 & 31,3 & 5 & 31,8 & 3 & 18,8 & 15 & & \\
\hline & $6-10$ & 1-2 gelas & 2 & 33,3 & 0 & 0 & 1 & 16,7 & 0 & 0 & 3 & \multirow{2}{*}{100} & \\
\hline & tahun & $>3$ gelas & 0 & 0 & 0 & 0 & 2 & 33,3 & 1 & 16,7 & 3 & & \\
\hline & $>10$ & 1-2 gelas & 0 & 0 & 0 & 0 & 0 & 0 & 0 & 0 & 0 & \multirow{2}{*}{100} & \\
\hline & tahun & $>3$ gelas & 0 & 0 & 0 & 0 & 1 & 100 & 0 & 0 & 1 & & \\
\hline \multirow{6}{*}{$\begin{array}{l}\text { kadang- } \\
\text { kadang }\end{array}$} & $0-5$ & 1-2 gelas & 4 & 44,4 & 1 & 11,1 & 0 & 0 & 0 & 0 & 5 & \multirow{2}{*}{100} & \multirow{6}{*}{0,08} \\
\hline & tahun & $>3$ gelas & 0 & 0 & 0 & 0 & 4 & 44,4 & 0 & 0 & 4 & & \\
\hline & $6-10$ & 1-2 gelas & 12 & 70,6 & 1 & 5,9 & 1 & 5,9 & 0 & 0 & 14 & \multirow{2}{*}{100} & \\
\hline & tahun & $>3$ gelas & 1 & 5,9 & 0 & 0 & 2 & 11,8 & 0 & 0 & 3 & & \\
\hline & $>10$ & 1-2 gelas & 2 & 50 & 0 & 0 & 0 & 0 & 0 & 0 & 2 & \multirow{2}{*}{100} & \\
\hline & tahun & $>3$ gelas & 2 & 50 & 0 & 0 & 0 & 0 & 0 & 0 & 2 & & \\
\hline
\end{tabular}

Tabel 5 Pengaruh frekuensi menggosok gigi terhadap erosi gigi $(\mathrm{p}<0,05=*$ signifikan $)$

\begin{tabular}{cccccccccccc}
\hline Frekuensi & \multicolumn{2}{c}{ Tidak ada erosi } & \multicolumn{2}{c}{ Lesi superfisial } & \multicolumn{2}{c}{ Lesi terlokalisasi } & \multicolumn{2}{c}{ Lesi general } & \multicolumn{2}{c}{ Total } & \multirow{2}{*}{ p } \\
menggosok gigi & $\mathrm{n}$ & $\%$ & $\mathrm{n}$ & $\%$ & $\mathrm{n}$ & $\%$ & $\mathrm{n}$ & $\%$ & $\mathrm{n}$ & $\%$ & \\
\hline 1x sehari & 5 & $11,6 \%$ & 6 & $14,0 \%$ & 16 & $37,2 \%$ & 16 & $37,2 \%$ & 43 & $100 \%$ & \\
2x sehari & 20 & $35,1 \%$ & 8 & $14,0 \%$ & 21 & $36,8 \%$ & 8 & $14,0 \%$ & 57 & $100 \%$ & 0,012 \\
\hline Total & 25 & $25 \%$ & 14 & $14 \%$ & 37 & $37 \%$ & 24 & $24 \%$ & 100 & $100 \%$ & \\
\hline
\end{tabular}

tuak yang dilihat dari nilai $\mathrm{P}=0,03$. Tidak terdapat pengaruh yang signifikan pada frekuensi konsumsi minuman tuak setiap minggu dan kadang-kadang, lamanya konsumsi minuman tuak, dan banyaknya minuman tuak yang dikonsumsi setiap kali minum.

Ujichi square (tabel 5) menunjukkan tidak ada pengaruh signifikan antara frekuensi menggosok gigi dalam sehari terhadap erosi pada peminum tuak yang dilihat dari nilai $\mathrm{p}=0,012$.

\section{PEMBAHASAN}

Erosi permukaan gigi didefinisikan sebagai hilangnya jaringan keras gigi dengan proses kimia yang tidak melibatkan bakteri. Proses erosi terjadi terus-menerus dalam berbagai tahap. Erosi pada gigi dimulai dengan pelepasan kalsium email. ${ }^{8}$ Proses ini dapat bervariasi sesuai dengan waktu terpaparnya danjenis asam yang terlibat. Jika erosi berlanjut, akan menyebabkan pelepasan kristal email yang hingga terbukanya dentin dan menimbulkan rasa ngilu. ${ }^{9}$

Pada penelitian ini, tampak wanita cenderung tidak memiliki erosi gigi karena umumnya wanita lebih menjaga kebersihan diri termasukoral hygiene nya dibanding dengan pria.

Erosi pada gigi paling banyak ditemukan pada responden pria berusia 31-40 tahun yang berprofesi sebagai petani. Hal tersebut disebabkanoleh beberapa faktor, seperti pria usia 31-40 merupakan responden terbanyak pada penelitian ini dan merupakan usia yang paling produktif diantara interval usia lainnya. Berdasarkan hasil wawancara dengan responden, dikatakan bahwa minuman tuak dapat menyegarkan badan setelah pulang dari bertani, menghilangkan stress, serta murah dan mudah untuk didapatkan.

Responden yang tidakmemiliki erosi gigi paling banyak ditemukan pada responden yang bertempat tinggal di Desa Puncak Harapan. Tuak pahit jarang dijumpai di Desa Puncak Harapan, sebab masyarakat Desa Puncak Harapan merupakan masyarakat yang religius. Sebagian besar dari responden yang hanya mengkonsumsi minuman manis didapatkan di Desa Puncak Harapan.

Terjadinya erosi gigi paling banyak ditemukan pada responden yang bertempat tinggal di Kelurahan Bangkala. Kelurahan Bangkala merupakan desa yang palingluas diantara desa lainnya sehingga responden yang paling banyak bertempat tinggal di Kelurahan tersebut. Berdasarkan letak geografisnya, Kelurahan Bangkala merupakan daerah dataran tinggi yang beriklim dingin sehingga masyarakat di kelurahan ini mengkonsumsi minuman tuak pahit yang dapat menghangatkan badan sepulang kerja.

Responden yang tidak memiliki erosi gigi paling banyak ditemukan pada mereka yang mengkonsumsi tuak manis saja. Berdasarkan hasil pengukuran derajat keasaman, minuman tuak manis yang diproduksi oleh 
ketiga desa tersebut memiliki $\mathrm{pH}$ yaitu 7 . Responden yang hanya mengkonsumsi minuman tuak manis tidak memiliki erosi gigi, karena erosi gigi terjadi apabila gigi geligi terpapar dengan minuman yang bersifat asam.

Semakin tinggi pH makanan dan minuman yang secara rutin dikonsumsi, mengakibatkan semakin seringnya gigi geligi terpapar oleh asam sehingga membuat lingkungan yang asampada rongga mulut. Apabila dibiarkan, akan mengakibatkan terlepasnya hidroksiapatit pada email gigi. ${ }^{10}$ Demineralisasi gigi terjadi apabila email berada dalam suatu lingkungan pH di bawah 5,5 atau asam. ${ }^{6}$

Minuman tuak pahit dengan $\mathrm{pH}$ di bawah 5,5 yang dikonsumsi oleh masyarakat memiliki pengaruh yang signifikan terhadap demineralisasi pada email gigi karena $\mathrm{pH}$ yang rendah akan meningkatkan konsentrasi ion $\mathrm{H}^{+}$yang akan merusak hidroksiapatit email gigi. Hal ini sesuai dengan penelitian yang dilakukan oleh Prasetyo yang menyimpulkan bahwa keasaman minuman yang kurang dari 7 atau bersifat asam dapat menurunkan kekerasan permukaan email gigi. ${ }^{11}$

Responden yang tidak memiliki erosi gigi paling banyak ditemukan pada responden yang tidak secara rutin mengkonsumsi 1-2 gelas minuman tuak selama 6-10 tahun. Erosi gigi paling banyak dijumpai pada responden yang tiap hari mengkonsumsi lebih dari 3 gelas selama lebih dari 10 tahun.

Hal ini disebabkan karena lamanya gigi terpapar oleh minuman yang mengandung asam. Semakin sering gigi geligi terpapar dengan makanan atau minuman yang memiliki $\mathrm{pH}$ di bawah normal, maka dapat membuat suasana asam di dalam mulut sehingga terjadi pengikisan email gigi. ${ }^{11,12}$

Hal ini sejalan dengan penelitian yang dilakukan oleh Imran dkk, yang menyimpulkan bahwa terdapat pengaruh minuman jus lemon kemasan terhadap kekerasan permukaan email. Lamanya perendaman gigi pada minuman lemon mempengaruhi tingkat penurunan kekerasan permukaan email. Semakin lama perendaman dilakukan maka semakin tinggi tingkat penurunan kekerasan permukaan email gigi. Padapenelitian tersebut,minumanjus lemon kemasan memiliki pH 3,6 (asam) yang hampir sama dengan minuman tuak yang memiliki $\mathrm{pH} 3-4 .^{12}$ Minuman yangmemiliki $\mathrm{pH}$ asam yang dikonsumsi secara terus menerus, menyebabkan demineralisasi gigi yang didukung oleh lama waktu terpaparnya permukaan gigi dengan minuman yang mengandung asam. ${ }^{7}$

Responden yang menggosok gigi 2 kali sehari tidak mengurangi risiko terjadi erosi gigi. Walaupun menggosok gigi secara teratur, erosi gigi masih dapat terjadi apabila menggosok gigi dengan cara yang tidak adekuat. Dari hasil wawancara, sebagian besar responden mengkonsumsi minuman tuak sampai mabuk, pada malam, sehingga mereka tidak sempat membersihkan gigi dan mulutnya terlebih dahulu sebelum tidur. Jadimulut dalam keadaan asam selama tidur, yang menyebabkan terlepasnya hidroksiapatit email gigi sehingga terjadilah erosi gigi.

Berdasarkan kajian yang telah dilakukan, dapat disimpulkan bahwa konsumsi tuak mempengaruhi terjadinya erosi gigi di Kecamatan Maiwa Kabupaten Enrekang. Untuk itu disarankan bagi peminum tuak pahit berhenti mengkonsumsi minuman tuak, atau berkumur dengan air dan menjaga kebersihan mulut setelah mengkonsumsi makanan atau minuman yang mengandung asamagar mengurangi risiko terjadinya erosi. Penelitian mengenai insidensi dan prevalensi erosi gigi pada peminum tuak pahit perlu dilakukan di daerah lain dengan jumlah sampel yang lebih besar dan mengukur $\mathrm{pH}$ mulut setelah konsumsi minuman tuak pahit saat melakukan pemeriksaan intra oral.

\section{DAFTAR PUSTAKA}

1. Tarigan R. Karies gigi. Ed 2. Jakarta: EGC; 2013. hal 47-52

2. Harshanur I. Anatomi gigi. Jakarta : EGC; 1991. hal 31

3. Lempang M. Pohon aren dan manfaat produksinya. Info Teknis Eboni 2013: 9(1): 44-50. [internet]. Available from URL: http://forda-mof.org/files/4.Mody_Lempang.pdf. Diakses pada 3 Januari 2014

4. Ikegami S. Tuak dalam masyarakat Batak Toba: Laporan singkat tentang aspek sosial-budaya penggunaan nira. Annual Report of the University of Shizuoka, Hamamatsu College 1997;5(11-3): 1-8: [internet]. Available from URL: http://bambi.u-shizuoka-ken.ac.jp/ kiyou4228021/11_3/11_3_5.pdf. Diakses pada 21 Desember 2013

5. Pranani D.Pengaruh paparan uap belerang terhadap erosi gigi [skripsi].Semarang:Universitas Diponegoro;2008

6. Singhal AC, Chandak S, Chamele J, Jain A, Gupta P, Thakur P. Indices for measuring dental erosion. Chhattisgarh J Health Sci 2013;1(1): 52-6. Available from URL: http://journal.cghealthuniv.com/pdfs/INDICES\%20FOR\%20 MEASURING\%20DENTAL\%20EROSION.pdf. Accessed on 2014, 20 June

7. Imfeld T. Dental erosion. Definition, classification and links. Eur J Oral Sci 1996; 104: 151-5 [internet]. Available from URL: http://www.geocities.ws/scientistconrad/Colgate_Erosion/Manuscripts/Dental_erosion_Definition classification_and_links.pdf. Accessed on 2014, 26 February

8. Yan-fang R.Dental erosion: etiology, diagnosis and prevention.2011.p.76-80.[internet].Available from URL: http://www. rdhmag.com/etc/medialib/new-lib/rdh/site-images/volume-31/issue-8/1108RDH075-085.pdf. Accesseon 2014, 30 June 
9. Vailati F. Classification and treatment of the anterior maxillary dentition affected by dental erosion: The ACE classification. Int J Periodont Restor Dent 2010:30(6): 559-71. [internet]. Available from URL:http://www.osteocom. net/osteocom/modules/Friend/images/acefinalissima_62058.pdf. Accessed on 2014, 30 June

10. Lussi A. Dental erosion from diagnosis to therapy. Switzerland: 2006. pp. 9-14, 17-24

11. Prasetyo EA. Keasaman minuman ringan menurunkan kekerasan permukaan gigi. Maj Ked Gigi 2005: 38(2): 60-3 [internet]. Available URL:http://www.journal.unair.ac.id/filerPDF/DENTJ-38-2-04.pdf. Accessed on 21 November 2013

12. Imran H, Nasry, Rohany. Pengaruh minuman jus lemon kemasan terhadap perubahan kekerasan email gigi berdasarkan durasi waktu. Penelitian Risbinakes 2012. Hal. 1-6 